\author{
A. M. Pasko* \\ * Oles Honchar Dnipro National University, \\ Dnipro 49050.E-mail:pasko08@meta.ua
}

\title{
The Betti numbers of the space $\mathbb{C} \Omega_{3}$
}

Запропоновану працю присвячено вивченню топологічного простору $\mathbb{C} \Omega_{3}$. Простори $\mathbb{C} \Omega_{n}$ є аналогом просторів узагальнених досконалих сплайнів $\Omega_{n}$ для випадку комплекснозначних функцій. Кожен сплайн простору $\mathbb{C} \Omega_{n}$ задається системою вузлів відрізка $[0,1]$ та системою чисел одиничного кола комплексної площини, які визначають значення сплайна на проміжках між вузлами. Цим комплекснозначні сплайни простору $\mathbb{C} \Omega_{n}$ відрізняються від узагальнених досконалих сплайнів простору $\Omega_{n}$, значення котрих на проміжках між вузлами задаються дійсними числами множини $\{ \pm 1\}$. Як і для простору $\Omega_{n}$, топологія простору $\mathbb{C} \Omega_{n}$ наслідувана з простору сумовних функцій $L_{1}$, в цьому випадку комплекснозначних. Систематичне дослідження гомотопічних інваріантів простору $\Omega_{n}$ було започатковане B.I. Рубаном, який побудував клітинну структуру цього простору, і з ї̈ допомогою 1985 року знайшов групи $n$-вимірних гомологій простору $\Omega_{n}$, а 1999 року повністю розв'язав задачу відшукання груп його когомологій. В подальшому гомотопічні інваріанти простору $\Omega_{n}$ вивчалися В.А. Кощеевим, який встановив однозв'язність $\Omega_{n}$, та А.М. Паськом, який знайшов гомотопічні групи цих просторів у вимірностях від 2 до $n$. Топологічні простори $\mathbb{C} \Omega_{n}$ було введено в роботі 2015 року А.М. Паськом, в якій автор побудував на $\mathbb{C} \Omega_{n}$ структуру клітинного простору, аналогічну введеній В.I. Рубаном клітинній структурі протору $\Omega_{n}$, і з її допомогою довів однозв'язність просторів $\mathbb{C} \Omega_{n}$ для всіх $n \geq 2$. У роботі 2016 року А.М. Пасько знайшов гомології простору $\mathbb{C} \Omega_{n}$ у вимірностях $0,1,2,2 n-1,2 n, 2 n+1$ (клітинний простір $\mathbb{C} \Omega_{n}$ має вимірність $2 n+1$ ), та встановив рівність нулю ейлерової характеристики простору $\mathbb{C} \Omega_{n}$ для всіх $n \geq 1$. У запропонованій статті досліджуються числа Бетті (ранги гомологічних груп) простору $\mathbb{C} \Omega_{3}$. Використовуючи обчислений у праці [3] явний вигляд оператора межі, в роботі знайдено безпосередньо групи 3-вимірних циклів та групи 3-вимірних меж простору $\mathbb{C} \Omega_{3}$, що дозволило знайти 3-вимірну групу гомологій цього простору. Враховучи відомі 3 [4] групи гомологій простору $\mathbb{C} \Omega_{3}$ у вимірностях $0,1,2,5,6,7$, знайдоно числа Бетті простору $\mathbb{C} \Omega_{3}$ у всіх вимірностях, крім вимірності 4. Число Бетті у вимірності 4 знаходимо шляхом підрахунку ейлерової характеристики. Таким чином, у статті знайдено всі числа Бетті простору $\mathbb{C} \Omega_{3}$.

Key words: узагальнений досконалий сплайн, клітинний простір, числа Бетті

The space $\mathbb{C} \Omega_{3}$ is considered. The Betti numbers of the space $\mathbb{C} \Omega_{3}$ are calculated.

Key words: generalized perfect spline, $C W$-complex, Betti numbers

MSC2010: Pri 41A10, SEC 41A44, 46E20

Let $\omega(t), t \geq 0$, be the non-negative, continuous increasing function, $\omega(0)=0$, and $n \in \mathbb{N}$. Consider integer $q \geq 0$ and the system of the knots

$$
0=\eta_{0}<\eta_{1}<\ldots<\eta_{q}<\eta_{q+1}=1 .
$$


Let $G$ be the real line $\mathbb{R}$ or the complex plane $\mathbb{C}$. Consider the function ( $\omega$-spline)

$$
F(\eta, s, t)=s_{k} \cdot \min \left\{\omega\left(t-\eta_{k}\right), \omega\left(\eta_{k+1}-t\right)\right\}, \quad \text { for } \quad t \in\left[\eta_{k}, \eta_{k+1}\right],
$$

with $s_{k} \in G,\left|s_{k}\right|=1$ and the subspace of the space $L_{1}[0,1]$ that consists of the splines (1) for $q \leq n$. If $G=\mathbb{R}$ this subspace coincides with the space $\Omega_{n}$, in case of $G=\mathbb{C}$ it coincides with the space $\mathbb{C} \Omega_{n}$. The researches of the homotopy invariants of the spaces $\Omega_{n}$ has been started by V.I. Ruban [5], [6] who has built CW structure on $\Omega_{n}$ and calculated the cohomologies of the space $\Omega_{n}$. V.A.Koshcheev [1] has proved that the spaces $\Omega_{n}$ are simply connected. A.M. Pasko [2] has established that the homotopy groups

$$
\pi_{k}\left(\Omega_{n}\right)= \begin{cases}0, & 2 \leq k \leq n-1, \\ \mathbb{Z}^{\frac{2^{n+2}+(-1)^{n+1}}{3}}, & k=n .\end{cases}
$$

The spaces $\mathbb{C} \Omega_{n}$ have been introduced in the paper [3]. In [3] A.M. Pasko has built on $\mathbb{C} \Omega_{n}$ the structure of $2 \mathrm{n}+1$ - dimensional $\mathrm{CW}$-complex and proved that the spaces $\mathbb{C} \Omega_{n}, n \geq 2$, are simply connected. In [4] A.M. Pasko has established that

$$
H_{k}\left(\mathbb{C} \Omega_{n}\right)= \begin{cases}\mathbb{Z}, & \text { якщо } k=0, k=2 n+1 ; \\ 0, & \text { якщо } k=1, k=2 ; \\ \mathbb{Z}^{n+\frac{(n-1)(n-2)}{2},}, & \text { якщо } k=2 n-1 ; \\ \mathbb{Z}^{n}, & \text { якщо } k=2 n .\end{cases}
$$

for any $n \geq 2$. So in [4] A.M. Pasko has found that the Euler characteristic $\chi\left(\mathbb{C} \Omega_{n}\right)=0$.

CW-complex is a Hausdorff space $E$ written as a union

$$
E=\bigcup_{q=0}^{\infty} \bigcup_{k \in I_{q}} e_{k}^{q}
$$

of the non-overlapping sets $e_{k}^{q}$ (q-cells) in such a way that any q-cell $e_{k}^{q}$ has a continuous characteristic map $f_{k}^{q}: D^{q} \rightarrow E$ of closed q-dimensional ball $D^{q}$ to E such that the restriction of $f_{k}^{q}$ to $\operatorname{Int} D^{q}$ is a homeomorphism between $\operatorname{Int} D^{q}$ and $e_{k}^{q}$. Herewith $\mathrm{E}$ satisfies the conditions:

(C) the boundary $\dot{e}_{k}^{q}=\bar{e}_{k}^{q} \backslash e_{k}^{q}$ of any q-cell lies in the union of a finite number of j-cells for $j<q$;

(W) subset $F \subset E$ is closed if and only if all the intersections $F \cap \bar{e}_{k}^{q}$ are closed.

The q-skeleton of the CW-complex $E$ is the union $\operatorname{ske}_{q}(E)=\bigcup_{j \leq q} e_{k}^{j}$. The CWcomplex $E$ is said to be finite if it consists of finite amount of cells.

Consider CW-complex E. The set of the q-cells of E may be used as the basis of a free abelian group $C_{q}(E)$. Elements of $C_{q}(E)$ are called q-chains. There are the homomorphisms of groups $\partial=\partial_{q}: C_{q}(E) \rightarrow C_{q-1}(E)$. This homomorphisms are called boundary operators. Consider the groups $Z_{q}(E)=\operatorname{Ker} \partial_{q}$ (the groups of $q$-cycles) 
and $B_{q}(E)=\operatorname{Im} \partial_{q+1}$ (the groups of $q$-boundaries). The identity $\partial_{q} \partial_{q+1}=0$ implies $B_{q}(E) \subset Z_{q}(E)$ that allows to define the homology groups $H_{q}(E)=Z_{q}(E) / B_{q}(E)$.

Let us describe the $\mathrm{CW}$-complex structure of $\mathbb{C} \Omega_{n}$ introduced in [3]. Consider the set of two symbols $A=\{1, e\}$, integer $0 \leq q \leq n$ and the sequences

$$
u=u_{0} u_{1} \ldots u_{q}, \quad u_{j} \in A .
$$

For each sequence $\mathrm{u}$ let $h(u)$ be the number of $u_{j}$ such that $u_{j}=e$. Each m-cell, $0 \leq m \leq 2 n+1$, is determined with some sequence $u=u_{0} u_{1} \ldots u_{q}$ where $m=q+h(u)$, we denote such m-cell as $c^{q}\left(u_{0} u_{1} \ldots u_{q}\right)$. It is proved in [3] that the boundary of the m-cell $c^{q}\left(u_{0} u_{1} \ldots u_{q}\right)$ is equal

$$
\partial c^{q}\left(u_{0} u_{1} \ldots u_{q}\right)=\sum_{k: u_{k}=1}(-1)^{k} c^{q-1}\left(u_{0} \ldots \hat{u}_{k} \ldots u_{q}\right),
$$

where $u_{0} \ldots \hat{u}_{k} \ldots u_{q}$ is the sequence $u_{0} \ldots u_{q}$ in which the symbol $u_{k}$ is missed.

Consider the 3-cells of the 7-dimensional CW-complex $\mathbb{C} \Omega_{3}$ :

$$
c^{3}(1111), c^{2}(11 e), c^{2}(1 e 1), c^{2}(e 11), c^{1}(e e) .
$$

By the virtue of (3) their boundaries are

$$
\partial c^{3}(1111)=\partial c^{2}(11 e)=\partial c^{2}(e 11)=\partial c^{1}(e e)=0,
$$

and

$$
\partial c^{2}(1 e 1)=c^{1}(e 1)+c^{1}(1 e) .
$$

Therefore $Z_{3}\left(\mathbb{C} \Omega_{3}\right)$ is a free abelian group with the basis

$$
c^{3}(1111), c^{2}(11 e), c^{2}(e 11), c^{1}(e e) .
$$

On the other hand

$$
c^{2}(11 e)=-\partial c^{3}(11 e 1), c^{2}(e 11)=\partial c^{3}(1 e 11), c^{1}(e e)=\partial c^{2}(1 e e),
$$

so $c^{2}(11 e), c^{2}(e 11), c^{1}(e e)$ are 3 -boundaries. The 3 -cell $c^{3}(1111)$ is boundary of no 4 chain because the codes of all the 4-cells of the space $\mathbb{C} \Omega_{3}$ unclude the symbol $e$, so the codes of their boundaries do. Therefore $H_{3}\left(\mathbb{C} \Omega_{3}\right)$ is the free abelian group with the basis $c^{3}(1111)$. Hence

$$
H_{3}\left(\mathbb{C} \Omega_{3}\right)=\mathbb{Z} .
$$

It follows from (2), (4) that

$$
H_{k}\left(\mathbb{C} \Omega_{3}\right)= \begin{cases}\mathbb{Z}, & \text { if } k=0,3,7 ; \\ 0, & \text { if } k=1, k=2 ; \\ \mathbb{Z}^{4}, & \text { if } k=5 ; \\ \mathbb{Z}^{3}, & \text { if } k=6 .\end{cases}
$$


So only $H_{4}\left(\mathbb{C} \Omega_{3}\right)$ is unknown. The equality (5) implies that the Betti numbers $\beta_{k}\left(\mathbb{C} \Omega_{3}\right), k \neq 4$ (the ranks of the homology groups) of the space $\mathbb{C} \Omega_{3}$ are equal

$$
\beta_{k}\left(\mathbb{C} \Omega_{3}\right)= \begin{cases}1, & \text { if } k=0,3,7 \\ 0, & \text { if } k=1, k=2 \\ 4, & \text { if } k=5 \\ 3, & \text { if } k=6\end{cases}
$$

It is known from [4] that the Euler characteristic $\chi\left(\mathbb{C} \Omega_{n}\right)=0, n \geq 1$. Thus

$$
\chi\left(\mathbb{C} \Omega_{3}\right)=\sum_{k=0}^{7}(-1)^{k} \beta_{k}\left(\mathbb{C} \Omega_{3}\right)=0 .
$$

It follows from $(6),(7)$ that $\beta_{4}\left(\mathbb{C} \Omega_{3}\right)=2$. So we have proved the theorem.

Theorem 1. The Betti numbers of the space $\mathbb{C} \Omega_{3}$ are

$$
\beta_{k}\left(\mathbb{C} \Omega_{3}\right)= \begin{cases}1, & \text { if } k=0,3,7 \\ 0, & \text { if } k=1, k=2 ; \\ 2, & \text { if } k=4 \\ 4, & \text { if } k=5 \\ 3, & \text { if } k=6 .\end{cases}
$$

\section{References}

1. Koshcheev V.A. The fundamental groups of the spaces of generalized perfect splines. Trudy Instituta Matematiki i Mekhaniki UrO RAN V. 15, №1. (2009), 159-165.

2. Pasko A. M. On the homotopy of the spaces of generalized perfect splines. Visn. Dnipro univ., Ser. Mat. 17 (2012), 138-140.

3. Pasko A. M. Simply connectedness of some space of the functions to complex numbers. Visn. Dnipro univ., Ser. Mat. 20 (2015), 70-74.

4. Pasko A. M. The homologies of the space $\mathbb{C} \Omega_{n}$ in some dimensions. Visn. Dnipro univ., Ser. Mat. 21 (2016), 71-76.

5. Ruban V. I. The CW-structure of the spaces of $\Omega$-splines. Issledovania po sovr. problemam summirovania i priblizhenia funkciy i ikh prilozheniam. Dnipropetrovsk. (1985), 39-40.

6. Ruban V. I. The CW-structure and the cohomology of the spaces of generalized perfect splines. Visn. Dnipro univ., Ser. Mat. 4 (1999), 85-90.

Received: 02.12.2019. Accepted: 20.12.2019 